\title{
Insulin Release and Cyclic AMP Accumulation in Response to Glucose in Pancreatic Islets of Fed and Starved Rats
}

\author{
A. Rabinovitch, V. Grill, A. E. Renold, and E. Cerasi \\ From the Institute of Clinical Biochemistry, Department of Medicine, University of \\ Geneva, Switzerland
}

A B S TRACT The dose as well as the time kinetics of insulin and adenosine-3',5'-monophosphate (cyclic AMP) responses to glucose were compared in pancreatic islets of fed and starved rats. There was a preferential impairment of the early phase of glucose-induced insulin release in perifused islets of rats starved for 16 and $48 \mathrm{~h}$. Similarly, the accumulation of ${ }^{3} \mathrm{H}$ cyclic AMP in islets prelabeled with ${ }^{3} \mathrm{H}$-2-adenine was less in islets of $48 \mathrm{~h}$ starved than fed rats, during the first 10-min of stimulation with $26.7 \mathrm{mM}$ glucose in the presence of $0.1 \mathrm{mM}$ of the phosphodiesterase inhibitor, 3-isobutyl-1-methylxanthine, whereas at 30 and $60 \mathrm{~min}{ }^{3} \mathrm{H}$ cyclic AMP responses to glucose were similar in fed and starved islets. Also, in 10-min incubations with glucose 3.3, $6.7,10.0,13.3$, and $26.7 \mathrm{mM}$ without and with 0.1 $\mathrm{mM}$ and $1.0 \mathrm{mM}$ 3-isobutyl-1-methylxanthine, insulin release correlated strongly with the accumulation of ${ }^{3} \mathrm{H}$ cyclic AMP in the islets of fed as well as starved rats. The thresholds for glucose-induced insulin and ${ }^{3} \mathrm{H}$ cyclic AMP responses were higher and the maximal responses were lower in starved than fed islets. Preincubation of islets of 48-h starved rats with $16.7 \mathrm{mM}$ glucose for 60 min corrected the impaired insulin and ${ }^{3} \mathrm{H}$ cyclic AMP responses to glucose. Starvation-induced impairment of insulin

Part of this work was previously reported in abstract form, Rabinovitch, A. 1975. Adenosine 3',5'-monophosphate (cAMP) and insulin responses to glucose in isolated pancreatic islets from fed and fasted rats. Diabetologia. 11: 371 .

Dr. Rabinovitch was a Centennial Fellow of the Medical Research Council of Canada.

Dr. Cerasi was a Visiting Professor at the University of Geneva, on sabbatical leave from the Department of Endocrinology and Metabolism, Karolinska Hospital, Stockholm, Sweden.

Received for publication 1 April 1976 and in revised form 4 August 1976.

The Journal of Clinical Investigation Volume 58 November 1976 $1209-1216$ secretory responses to glucose, and their restoration by preincubation with glucose in vitro, may represent acute regulatory effects of glucose on the adenylate cyclase-cyclic AMP system in the pancreatic beta cell.

\section{INTRODUCTION}

It is well documented in all species thus far studied, in vivo (1-7) and in vitro (8-13), that starvation results in an impairment of glucose-stimulated insulin secretion. This impairment is not complete, rather there is a decreased sensitivity to glucose of the insulin secretory mechanism $(10,14,15)$, and glucose refeeding in vivo $(2,4,7,16)$, or in vitro (15) has been reported to overcome this defect. It has been proposed that starvation specifically impairs a glucose-inducible enzyme system in the pancreatic beta cell $(3,7)$. Since the mechanisms which normally regulate insulin secretion are not well defined (17), it is hardly surprising that the nature of the impaired mechanism of insulin release observed in starvation has not been established.

Recent observations appear to link adenosine$3^{\prime}, 5^{\prime}$-monophosphate (cyclic AMP) ${ }^{1}$ levels in islets with the decreased insulin release observed in starvation. Howell et al. (18) have shown that basal as well as glucagon-stimulated adenylate cyclase activity is decreased in islets of 48-h starved rats, and these authors have suggested that glucose, or a glucose metabolite, may exert long-term effects on this enzyme. Selawry et al. (19) found a decreased content of cyclic AMP in islets of rats starved for $48-72 \mathrm{~h}$, and Capito and Hedeskov (20) observed that glucose

Abbreviations used in this paper: Cyclic AMP, adenosine3',5'-monophosphate; IBMX, 3-isobutyl-1 methylxanthine; KRB, Krebs- Ringer bicarbonate. 
TABLE I

Effects of Starvation on Body Weight, Plasma Glucose and Insulin Concentrations, and Islet

Insulin Content

\begin{tabular}{lccccc}
\hline $\begin{array}{c}\text { Nutrition } \\
\text { of rats }\end{array}$ & $\begin{array}{c}\text { No. of } \\
\text { animals }\end{array}$ & $\begin{array}{c}\text { Body } \\
\text { weight }\end{array}$ & $\begin{array}{c}\text { Plasma } \\
\text { glucose }\end{array}$ & $\begin{array}{c}\text { Plasma } \\
\text { insulin }\end{array}$ & $\begin{array}{c}\text { Islet } \\
\text { insulin } \\
\text { content }\end{array}$ \\
\hline & & $g$ & $m g / 100 \mathrm{ml}$ & $\mathrm{ng} / \mathrm{ml}$ & ng/islet \\
Fed & 10 & $237 \pm 10$ & $116 \pm 5$ & $2.76 \pm 0.28$ & $34.2 \pm 2.2$ \\
Starved $16 \mathrm{~h}$ & 12 & $266 \pm 9$ & $82 \pm 4^{*}$ & $1.28 \pm 0.18 \downarrow$ & $39.5 \pm 4.8$ \\
Starved $48 \mathrm{~h}$ & 10 & $203 \pm 11$ & $88 \pm 4^{*}$ & $1.44 \pm 0.17 \downarrow$ & $33.8 \pm 2.4$ \\
\hline
\end{tabular}

All values are mean \pm SEM.

${ }^{*} P<0.02$, according to Student's $t$ test, compared to fed rats. $\ddagger P<0.01$.

increased the cyclic AMP content in islets of fed, but not $48 \mathrm{~h}$ starved mice. Furthermore, insulin responses of starved islets to glucose (14), as well as to several other insulinotropic agents (21), were restored to normal by the addition of the phosphodiesterase inhibitor, caffeine.

The purpose of this study was to examine further the relationship between the impairment of insulin secretion observed in starvation, and the activity of the islet adenylate cyclase-cyclic AMP system in this condition. Accordingly, the dose as well as the time kinetics of insulin and cyclic AMP responses to glucose were compared in pancreatic islets isolated from fed and starved rats.

\section{METHODS}

Preparation of islets. Male Wistar rats weighing 200 $250 \mathrm{~g}$ were either fed on a standard laboratory diet ad libitum, or starved for 16 or $48 \mathrm{~h}$ until decapitation. Pancreatic islets were isolated by the method of Lacy and Kostianovsky (22). Each pancreas was minced with scissors and incubated at $37^{\circ} \mathrm{C}$ for 5-6 min, with shaking, in $2 \mathrm{ml}$ Hank's solution equilibrated to $\mathrm{pH} 7.4$ with $95 \%$ $\mathrm{O}_{2}: 5 \% \mathrm{CO}_{2}$, and containing $2.8 \mathrm{mM}$ glucose and $8 \mathrm{mg}$ collagenase (type I, Worthington Biochemical Corp., Freehold, N. J.).

Perifusion experiments. For each experiment 40 islets were transferred into each of two perifusion chambers in parallel, and the insulin content of two groups of 40 islets was also measured after acid-ethanol extraction (23). The perifusion system as applied to pieces of whole pancreas has been previously described (24). The basic medium was Krebs-Ringer bicarbonate (KRB) buffer continuously gassed with $95 \% \quad \mathrm{O}_{2}: 5 \% \quad \mathrm{CO}_{2}$, warmed at $37^{\circ} \mathrm{C}$, and containing $5 \mathrm{mg} / \mathrm{ml}$ of bovine serum albumin and $2.8 \mathrm{mM}$ glucose. The islets were perifused at a constant flow rate of $2.0-2.5 \mathrm{ml} / \mathrm{min}$, for an initial $30 \mathrm{~min}$ equilibration period with $2.8 \mathrm{mM}$ glucose, followed by a 30 -min stimulation period with $16.7 \mathrm{mM}$ glucose, then a return to $2.8 \mathrm{mM}$ glucose for $10 \mathrm{~min}$. The effluent from each chamber was collected in 1-min periods by using fraction collectors, and the insulin output rate was calculated as the product of the insulin concentration measured in the effluent and the perifusion flow rate.
Labeling with ${ }^{3} \mathrm{H}$ adenine and incubation of islets. The technique of labeling islet ATP during a period of preincubation was adapted from Kuo and DeRenzo (25) and Humes et al. (26). The total batch of islets $(1,000-2,000)$, obtained from four to eight rats, was preincubated at $37^{\circ} \mathrm{C}$ for $60 \mathrm{~min}$ in $2.5 \mathrm{ml} \mathrm{KRB}$ buffer containing $5 \mathrm{mg} / \mathrm{ml}$ of dialyzed bovine serum albumin, $2.8 \mathrm{mM}$ glucose, and 100 $\mu \mathrm{Ci} / \mathrm{ml}{ }^{3} \mathrm{H}$-2-adenine $(25 \mathrm{Ci} / \mathrm{mmol}$; New England Nuclear, Dreieichenhain, W. Germany). The islets were then washed four times with $10 \mathrm{ml}$ of the radioactive-free incubation buffer and transferred to a Petri dish.

In the first set of experiments, groups of 25 islets were incubated at $37^{\circ} \mathrm{C}$ in $1.0 \mathrm{ml} \mathrm{KRB}$ buffer containing $5 \mathrm{mg} / \mathrm{ml}$ of albumin and $3.3,6.7,10.0,13.3$, or $26.7 \mathrm{mM}$ glucose alone and with 0.1 , or $1.0 \mathrm{mM}$ 3-isobutyl-1-methylxanthine (IBMX, Aldrich Chemical Co. Inc., Milwaukee, Wis.). After $30 \mathrm{~s}-60 \mathrm{~min}$ of incubation, $0.1 \mathrm{ml}$ of medium was removed for insulin assay and $0.5 \mathrm{ml}$ for measuring the accumulation of ${ }^{3} \mathrm{H}$ cyclic AMP in the incubation medium. $100 \mu \mathrm{g}$ of unlabeled cyclic AMP was added to the remaining $0.4 \mathrm{ml}$ of medium containing the islets, and this was boiled for $5 \mathrm{~min}$. The islet content of cyclic AMP was calculated as the difference between the ${ }^{3} \mathrm{H}$ cyclic AMP in the medium before and after boiling.

In a second set of experiments, after the 60 -min preincubation with ${ }^{3} \mathrm{H}$-2-adenine, one-half of the total batch of islets $(1,000-2,000)$ was incubated at $37^{\circ} \mathrm{C}$ for $60 \mathrm{~min}$ in $2.5 \mathrm{ml} \mathrm{KRB}$ buffer containing $5 \mathrm{mg} / \mathrm{ml}$ of albumin and $3.3 \mathrm{mM}$ glucose, and the other half of the islets was incubated with $16.7 \mathrm{mM}$ glucose. The islets were then washed four times with the incubation buffer containing $3.3 \mathrm{mM}$ glucose and transferred to separate Petri dishes. Groups of 25 islets were then randomly distributed to vials containing $1.0 \mathrm{ml} \mathrm{KRB}$ buffer with $5 \mathrm{mg} / \mathrm{ml}$ of albumin and $3.3,6.7$, $10.0,13.3$, or $26.7 \mathrm{mM}$ glucose, and incubated at $37^{\circ} \mathrm{C}$ for $10 \mathrm{~min}$. The interval between the preincubation with 3.3 or $16.7 \mathrm{mM}$ glucose and the final $10-\mathrm{min}$ incubations was between 15 and $40 \mathrm{~min}$.

Measurements of ${ }^{3} \mathrm{H}$ cyclic AMP. The separation of ${ }^{3} \mathrm{H}$ cyclic AMP from other radioactive substances was performed by ion exchange chromatography and barium sulfate precipitation as described by Krishna et al. (27). Briefly, the incubation media and the boiled islet extracts, each containing $100 \mu \mathrm{g}$ of unlabeled cyclic AMP (as carrier), were adjusted to $1.0 \mathrm{ml}$ with water and put onto columns $(4 \times 0.6 \mathrm{~cm})$ of Dowex $50 \times 4,200-400 \mathrm{mesh}$, $\mathrm{H}^{+}$form (Fluka, Buchs, Switzerland), and eluted with water. Cyclic AMP was collected in the 5th- and 6th-ml fraction, and this was further treated by $\mathrm{BaSO}_{4}$ precipitation of impurities, which were removed by centrifugation. Portions $(0.2 \mathrm{ml})$ of the supernate were taken for determination of optical density (at $260 \mathrm{~nm}$ wave length) of the carrier cyclic AMP added before purification, to correct for losses (50-60\%) of ${ }^{3} \mathrm{H}$ cyclic AMP during this procedure. The rest of the supernate $(2.2 \mathrm{ml})$ was counted in 6 $\mathrm{ml}$ Instagel in a Beckman liquid scintillation counter. (Beckman Instruments, Inc., Fullerton, Calif.) The efficiency of the above procedure for separation of ${ }^{3} \mathrm{H}$ cyclic AMP from other radioactive substances was confirmed by phosphodiesterase treatment and measurement of the resulting ${ }^{3} \mathrm{H}$ 5'AMP (28).

Measurements of total cyclic AMP. Groups of 100 islets were incubated at $37^{\circ} \mathrm{C}$ for $10 \mathrm{~min}$ in $50 \mu \mathrm{l} \mathrm{KRB}$ buffer containing $5 \mathrm{mg} / \mathrm{ml}$ of albumin plus test agents. Incubations were stopped by addition of $100 \mu \mathrm{l}$ acetate buffer and boiling for $5 \mathrm{~min}$. Boiled extracts of $50 \mu \mathrm{l}$ (in duplicate) were taken for cyclic AMP determination by a protein binding assay employing protein kinase from muscle, 
as described by Gilman (29). Standard curves were run in medium treated in the same manner as the sample extracts.

Insulin and glucose assays. Insulin was measured by using a charcoal separation method of radioimmunoassay (30). Monocomponent porcine insulin (kindly supplied by Dr. J. Schlichtkrull, Novo Research Institute, Bagsvaerd, Denmark), was iodinated with ${ }^{125}$ iodine (EIDG. Institut Fur Reaktorforschung, Würenlingen, Switzerland), by using the chloramine-T method of Hunter and Greenwood (31), and purified on G50 Sephadex (Pharmacia Fine Chemicals, Uppsala, Sweden). Purified rat insulin (Novo Research Institute) was used as standard and guinea-pig antiporcine insulin antiserum (kindly provided by Dr. P. H. Wright, Indiana University, Indianapolis, Ind.) was used as antibody in the radioimmunoassay.

Plasma glucose was measured by a glucose-oxidase method (32), by using reagents kindly donated by Dr. F. Schmidt, C. F. Boehringer and Sons, Mannheim, GmbH, W. Germany.

\section{RESULTS}

Effects of starvation on plasma glucose and insulin concentrations and on islet insulin content. Rats starved for $16 \mathrm{~h}$ weighed about $5 \%$ less than fed controls and had significantly lower concentrations of plasma glucose and insulin (Table I). Rats starved for $48 \mathrm{~h}$ weighed about $14 \%$ less than fed controls, but exhibited no further decrease in the concentration of either plasma glucose or insulin. There was no

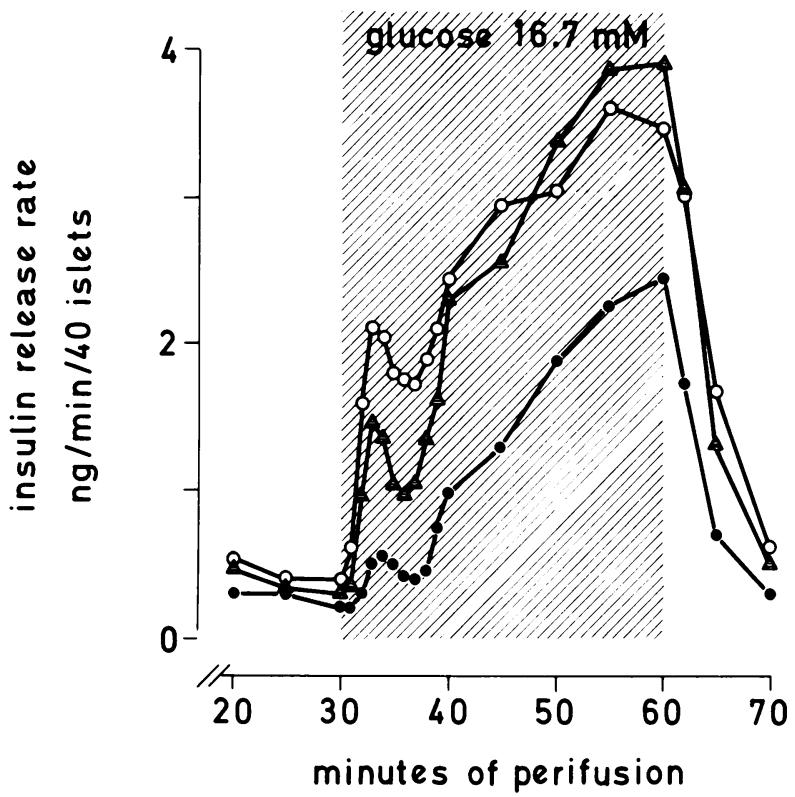

Figure 1 Mean rates of insulin release from islets of fed rats $(O, n=5$ experiments) 16 -h starved rats ( $\triangleq, n=6$ experiments) and 48 -h starved rats $(\bullet, n=5$ experiments), during perifusion with $2.8 \mathrm{mM}$ glucose for $30 \mathrm{~min}$ (only last $10 \mathrm{~min}$ shown) followed by an increase in the perifusion medium glucose concentration to 16.7 $\mathrm{mM}$ for $30 \mathrm{~min}$, then a return to $2.8 \mathrm{mM}$ glucose for 10 $\min$.
TABLE II

Effects of Starvation on the Early (I) and Late (II) Phases of Glucose-Induced Insulin Release in Perifused Islets

\begin{tabular}{|c|c|c|c|c|c|}
\hline \multirow{2}{*}{$\begin{array}{l}\text { Nutrition } \\
\text { of rats }\end{array}$} & \multirow{2}{*}{$\begin{array}{l}\text { No. of } \\
\text { perifu- } \\
\text { sions }\end{array}$} & \multicolumn{4}{|c|}{ Insulin release, $n g / 40$ islets ${ }^{*}$} \\
\hline & & Phase I & Phase II & Total & Phase I/Total \\
\hline & & & & & $\%$ \\
\hline Fed & 5 & $9.2 \pm 1.3$ & $69.6 \pm 14.7$ & $79.5 \pm 16.0$ & $14.0 \pm 1.3$ \\
\hline Starved $16 \mathrm{~h}$ & 6 & $5.8 \pm 0.9$ & $69.9 \pm 12.4$ & $75.9 \pm 13.7$ & $7.7 \pm 0.8 \S$ \\
\hline Starved $48 \mathrm{~h}$ & 5 & $2.3 \pm 0.5 \S$ & $38.0 \pm 5.3 \ddagger$ & $40.5 \pm 5.6$ & $6.2 \pm 1.1 \S$ \\
\hline
\end{tabular}

* Mean values $\pm S E M$ integrated over the first $6 \mathrm{~min}$ (phase I), and from 7 to 30 min (phase II) during perifusion with $16.7 \mathrm{mM}$ glucose.

$\ddagger P<0.05$, according to Student's $t$ test, compared to fed rats. $\S P<0.005$.

significant change in the content of insulin in islets of rats starved for 16 or $48 \mathrm{~h}$ compared to fed controls.

Effects of starvation on glucose-stimulated insulin release from perifused islets. Basal insulin release rates at the end of a 30 -min period of perifusion with $2.8 \mathrm{mM}$ glucose were lower in islets of $48 \mathrm{~h}$ starved rats $(0.20 \pm 0.06 \mathrm{ng} / \mathrm{min} / 40$ islets $)$ and $16-\mathrm{h}$ starved rats $(0.31 \pm 0.09 \mathrm{ng} / \mathrm{min} / 40$ islets $)$ than in islets of fed rats $(0.39 \pm 0.07 \mathrm{ng} / \mathrm{min} / 40$ islets), however the differences were not statistically significant (Fig. 1). There was a significant increase in the rate of insulin release from islets of fed rats at $1 \mathrm{~min}$ after increasing the glucose concentration in the perifusate from 2.8 to $16.7 \mathrm{mM}$, but not until 2 min in islets of 16-h starved rats, and $3 \mathrm{~min}$ in islets of $48 \mathrm{~h}$ starved rats. Furthermore, there was a progressive decrease in the early phase of glucoseinduced insulin release in islets of rats starved for 16 and $48 \mathrm{~h}$, whereas the later phase was significantly less only in islets of rats starved for $48 \mathrm{~h}$ (Table II). Phase I insulin release represented 14.0 $\pm 1.3 \%$ of the total insulin release in islets of fed rats, $7.7 \pm 0.8 \%$ in islets of 16 -h starved rats, and 6.2 $\pm 1.1 \%$ in islets of 48 -h starved rats, thereby indicating that starvation resulted in a relatively greater decrease in the early than the late phase of glucoseinduced insulin release.

Time-course of the effects of glucose on insulin release and ${ }^{3} \mathrm{H}$ cyclic AMP formation in islets of fed and starved rats. Fig. 2 shows that in incubations with $0.1 \mathrm{mM}$ of the phosphodiesterase inhibitor, IBMX, $26.7 \mathrm{mM}$ glucose stimulated significant increases of ${ }^{3} \mathrm{H}$ cyclic AMP in islets of fed rats $(30 \mathrm{~s})$ sooner than in islets of $48-\mathrm{h}$ starved rats $(1 \mathrm{~min})$. Similarly, glucose stimulated a significant increase of insulin release at $2 \mathrm{~min}$ in islets of fed rats and only at $5 \mathrm{~min}$ in islets of 48 -h starved rats. Thus, significant increases of ${ }^{3} \mathrm{H}$ cyclic AMP were detected in islets of fed as well as starved rats before insulin 
release was significantly stimulated in either case. Insulin release and islet levels of ${ }^{3} \mathrm{H}$ cyclic AMP were less in starved than fed islets during the first 10-30 min, but not at $60 \mathrm{~min}$ of stimulation with $26.7 \mathrm{mM}$ glucose (see legend to Fig. 2).

Glucose dose-response relationships for insulin release and ${ }^{3} \mathrm{H}$ cyclic AMP accumulation in islets of fed and starved rats. Fig. 3 shows that insulin and ${ }^{3} \mathrm{H}$ cyclic AMP responses in $10-\mathrm{min}$ incubations with different concentrations of glucose were less in islets of 48-h starved than fed rats, in the absence as well as in the presence of 0.1 or $1.0 \mathrm{mM}$ IBMX. Furthermore, the starved islets were less sensitive to glucose, in terms of both insulin release and ${ }^{3} \mathrm{H}$ cyclic AMP accumulation. Thus, the threshold concentration of glucose required to stimulate a significant increase of insulin release above basal (with $3.3 \mathrm{mM}$
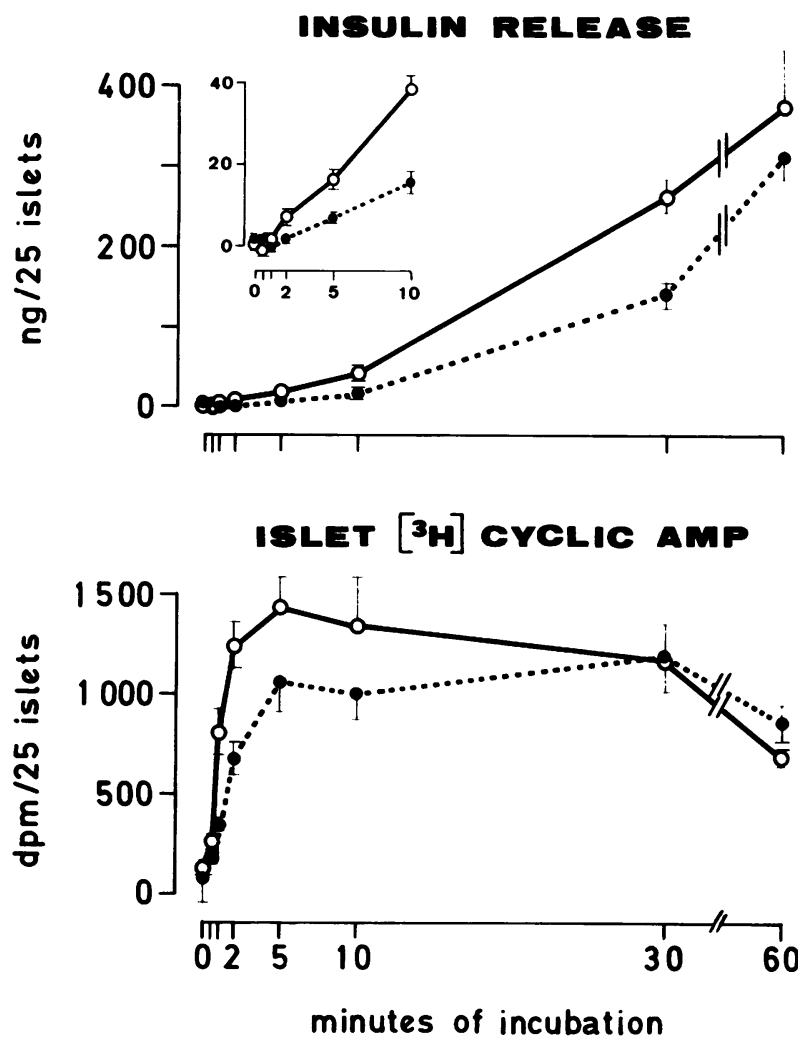

Figure 2 Time-course of the effects of $26.7 \mathrm{mM}$ glucose on insulin release and accumulation of ${ }^{3} \mathrm{H}$ cyclic AMP in islets of fed $(\mathrm{O}-O)$ and $48 \mathrm{~h}$ starved $\left(\mathrm{O}_{---O}\right)$ rats. Data are plotted as mean values \pm SEM for the differences between eight (fed islets) and six (starved islets) parallel incubations with 26.7 and $3.3 \mathrm{mM}$ glucose. IBMX (0.1 $\mathrm{mM}$ ) was present in all incubations. Insulin release was significantly less (Student's $t$ test) in starved than fed islets at $2 \mathrm{~min}(P<0.05), 5 \mathrm{~min}(P<0.05), 10 \mathrm{~min}(P$ $<0.001)$, and $30 \mathrm{~min}(P<0.001)$; and ${ }^{3} \mathrm{H}$ cyclic AMP accumulation was significantly less in starved islets at 1 $\min (P<0.01)$ and $2 \min (P<0.01)$.

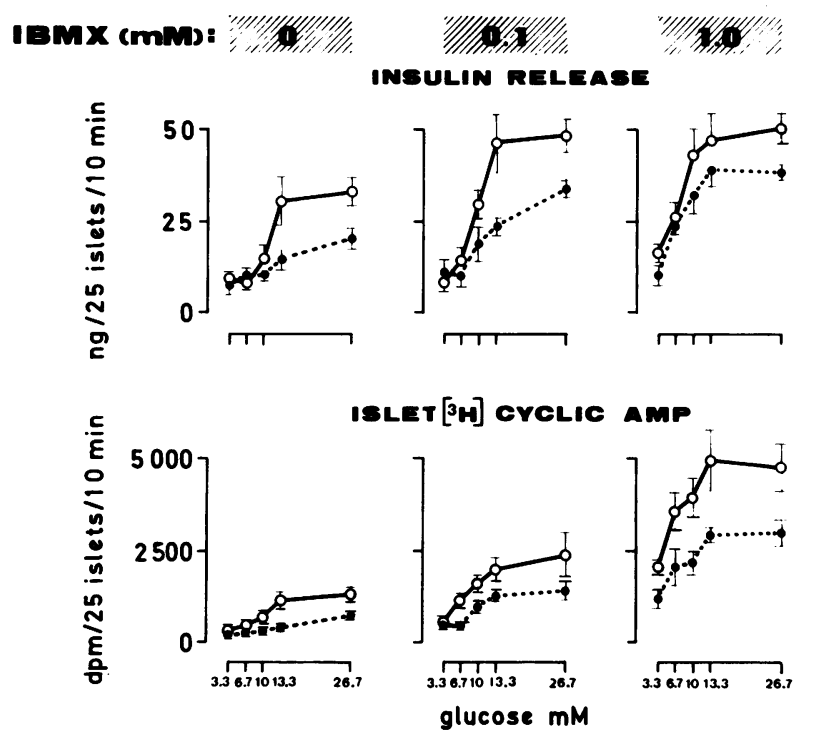

Figure 3 Glucose dose-response relationships for insulin release and accumulation of ${ }^{3} \mathrm{H}$ cyclic AMP in islets of fed $(\mathrm{O}-\mathrm{O})$ and 48-hr starved $\left(\mathrm{O}_{---O)}\right.$ rats, incubated without and with 0.1 and $1.0 \mathrm{mM}$ IBMX. Data are plotted as mean values \pm SEM for five (fed islets) and six (starved islets) parallel incubations with and without IBMX at each glucose concentration.

glucose alone) was $13.3 \mathrm{mM}$ in fed islets and 26.7 $\mathrm{mM}$ in starved islets without IBMX, $10.0 \mathrm{mM}$ in fed islets and $13.3 \mathrm{mM}$ in starved islets with $0.1 \mathrm{mM}$ IBMX, and $6.7 \mathrm{mM}$ in both fed and starved islets with $1.0 \mathrm{mM}$ IBMX. Since fed islets were not tested with glucose concentrations below $3.3 \mathrm{mM}$, it is not clear whether this concentration is already stimulatory in the presence of $1.0 \mathrm{mM}$ IBMX. Similarly, the threshold concentrations of glucose required to stimulate a significant increase of ${ }^{3} \mathrm{H}$ cyclic AMP above basal was $13.3 \mathrm{mM}$ in fed islets and 26.7 $\mathrm{mM}$ in starved islets without IBMX, $6.7 \mathrm{mM}$ in fed islets and $10.0 \mathrm{mM}$ in starved islets with $0.1 \mathrm{mM}$ IBMX, and $6.7 \mathrm{mM}$ in fed islets and $10 \mathrm{mM}$ in starved islets with $1.0 \mathrm{mM}$ IBMX. In these short $(10 \mathrm{~min})$ incubations, IBMX did not correct the impaired insulin and cyclic AMP responses to glucose; however, $0.1 \mathrm{mM}$, as well as $1.0 \mathrm{mM}$ IBMX amplified the dose-dependent effects of glucose similarly in fed and starved islets.

Furthermore, there were strong correlations between insulin release and ${ }^{3} \mathrm{H}$ cyclic AMP accumulation in the islets of either fed or starved rats, without and with IBMX (Fig. 4). Also, the slopes of the regression lines ( $b$, regression coefficients) were similar in fed and starved islets in the absence, as well as in the presence of $0.1 \mathrm{mM}$ and $1.0 \mathrm{mM}$ IBMX. This indicates that insulin release bears the same relationship to levels of cyclic AMP in 


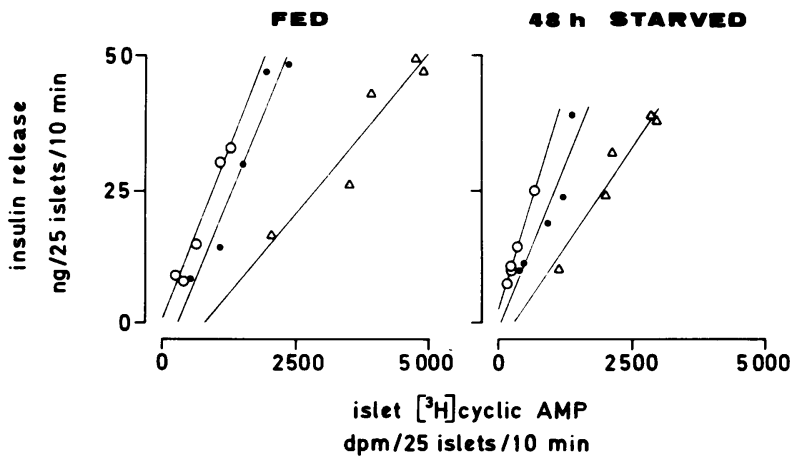

Figure 4 Correlations between insulin release and ${ }^{3} \mathrm{H}$ cyclic AMP accumulation in islets of fed and 48-h starved rats. Data are taken from the experiments shown in Fig. 3, in which islets were incubated for $10 \mathrm{~min}$ with 3.3-26.7 mM glucose alone (O), with glucose plus IBMX $0.1 \mathrm{mM}(\odot)$, and with glucose plus IBMX $1.0 \mathrm{mM}(\triangle)$. The coefficients of correlation ( $r$ ) were: in fed islets, 0.98 $(\bigcirc), 0.97(O)$, and $0.94(\triangle)$; and in starved islets, $0.99(\mathrm{O})$, $0.93(\circlearrowleft)$, and $0.97(\triangle)$. The regression coefficients (b, mean \pm SEM) were: in fed islets, $0.032 \pm 0.009(O), 0.025$ \pm 0.010 (O), and $0.010 \pm 0.002(\triangle, P<0.05$ vs. $O)$; and in starved islets, $0.033 \pm 0.004(\bigcirc), 0.023 \pm 0.006(\odot)$, and $0.013 \pm 0.003(\triangle, P<0.01$ vs. $\bigcirc)$.

starved as in fed islets, i.e. the sensitivity of insulin release to cyclic AMP was similar in fed and starved islets. However, insulin release in both fed and starved islets was progressively less sensitive to increases in cyclic AMP with increasing concentrations of IBMX, as indicated by the progressively smaller regression coefficients (see legend to Fig. 4). Thus, the phosphodiesterase inhibitor was not as effective as glucose alone in stimulating insulin release.

Effects of a 60-min preincubation with glucose on the subsequent insulin and ${ }^{3} \mathrm{H}$ cyclic $A M P$ responses to glucose in islets of fed and starved rats. Fig. 5 shows that when islets of either fed or 48-h starved rats were preincubated for $60 \mathrm{~min}$ with 16.7 $\mathrm{mM}$ glucose, the subsequent glucose-induced insulin as well as ${ }^{3} \mathrm{H}$ cyclic AMP responses were greater than those observed in islets preincubated for 60 min with $3.3 \mathrm{mM}$ glucose. It is also apparent that the 60-min preincubation with $16.7 \mathrm{mM}$ glucose had greater effects on islets from starved than fed rats, the dose-response curves in these two nutritional states now becoming quite similar. Thus, the decreased stimulation of both insulin release and cyclic AMP formation in islets of rats starved for $48 \mathrm{~h}$ could be entirely reversed by a 60 -min preincubation of the islets in a high glucose concentration.

Comparative effects of glucose and IBMX on ${ }^{3} \mathrm{H}$ cyclic AMP formation and total cyclic AMP content in islets of fed and starved rats. The total cyclic AMP content in islets of fed and 48-h starved rats was measured by the protein kinase binding method
(29), to determine whether the effects of glucose and IBMX on the accumulation of ${ }^{3} \mathrm{H}$ cyclic AMP in islets prelabeled with ${ }^{3} \mathrm{H}$ adenine reflected changes in total islet cyclic AMP content. Table III shows that basal levels of cyclic AMP (with $3.3 \mathrm{mM}$ glucose) were slightly, but not significantly lower in islets of $48 \mathrm{~h}$ starved than fed rats, as measured by either method. $26.7 \mathrm{mM}$ glucose stimulated a greater increase in the accumulation of ${ }^{3} \mathrm{H}$ cyclic AMP in fed than starved islets, and the levels of ${ }^{3} \mathrm{H}$ cyclic AMP with $26.7 \mathrm{mM}$ glucose were significantly greater in fed than starved islets $(P<0.025)$ Similarly, 26.7 $\mathrm{mM}$ glucose increased total cyclic AMP in fed islets more than in starved islets, and the latter increase was not significant. However, it is apparent that the glucose-stimulated increase in total cyclic AMP was considerably less than the increase in ${ }^{3} \mathrm{H}$ cyclic AMP in islets of either fed or starved rats. This may be due to the less favourable incubation condition for glucose action (100 islets in only $50 \mu$ l, necessi-
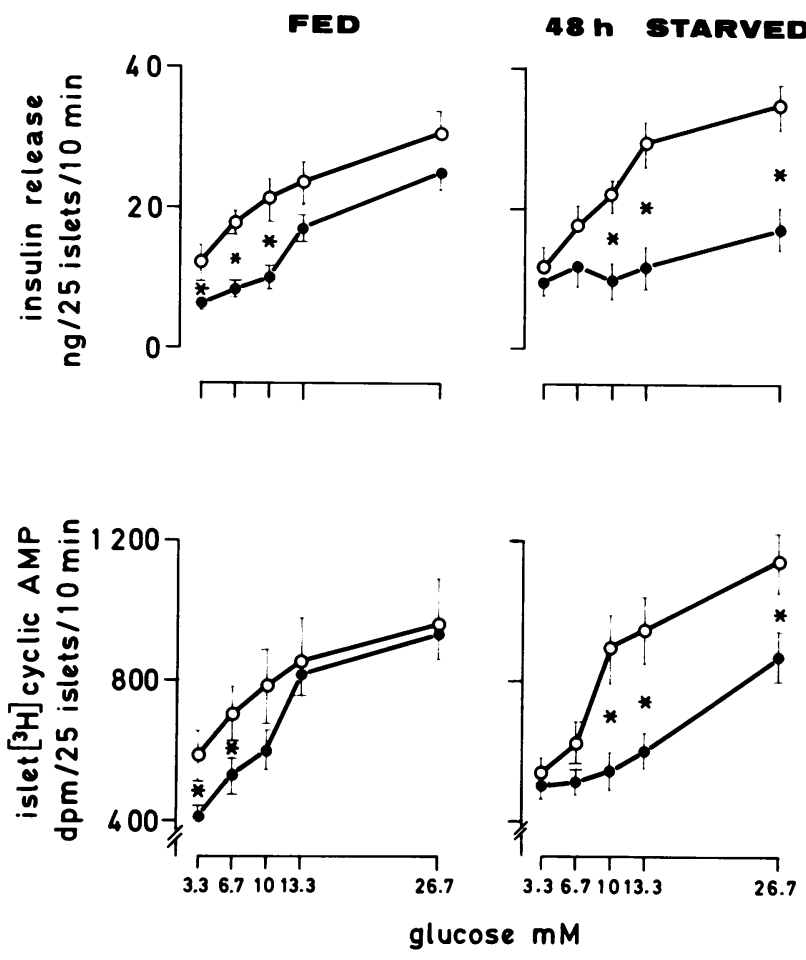

FIGURE 5 Effects of a 60-min preincubation with 3.3 $\mathrm{mM}(0)$ or $16.7 \mathrm{mM}$ (O) glucose (followed by a 15-40min interval at room temperature with $3.3 \mathrm{mM}$ glucose) on the subsequent insulin and ${ }^{3} \mathrm{H}$ cyclic AMP responses to glucose during 10-min incubations of islets of fed and 48-h starved rats. Data are plotted as mean values \pm SEM for six (fed islets) and six (starved islets) parallel incubations with each preincubation glucose concentration.

* Indicate that the values for preincubations with 3.3 and $16.7 \mathrm{mM}$ glucose were significantly different by Student's $t$ test $(P<0.05$ or less $)$. 
TABLE III

Effects of Glucose $\pm I B M X$ on Accumulation of ${ }^{3} \mathrm{H}$ Cyclic AMP and Total Cyclic AMP in Islets of Fed and Starved Rats

\begin{tabular}{cccccc}
\hline $\begin{array}{c}\text { Glucose } \\
\text { concen- } \\
\text { tration }\end{array}$ & $\begin{array}{c}\text { IBMX } \\
\text { concen- } \\
\text { tration }\end{array}$ & $\begin{array}{c}\text { Islet }\left[{ }^{3} \mathrm{H}\right] \text { cyclic AMP } \\
\text { accumulation* }\end{array}$ & $\begin{array}{c}\text { Total cyclic AMP } \\
\text { content }\end{array}$ \\
\hline$m M$ & $m M$ & dpm/islet $/ 10 \mathrm{~min}$ & fmol/islet $/ 10 \mathrm{~min}$ \\
& & Fed & $48 \mathrm{~h}$ starved & Fed & $48 \mathrm{~h}$ starved \\
3.3 & 0 & $9.9 \pm 2.0$ & $6.4 \pm 0.5$ & $8.8 \pm 1.0$ & $7.0 \pm 1.3$ \\
26.7 & 0 & $50.8 \pm 6.6$ & $27.0 \pm 2.7$ & $16.5 \pm 1.5$ & $11.0 \pm 2.0$ \\
3.3 & 1.0 & $82.3 \pm 4.7$ & $45.6 \pm 9.7$ & $65.0 \pm 7.0$ & $47.0 \pm 6.8$ \\
26.7 & 1.0 & $191.6 \pm 25.2$ & $119.0 \pm 14.0$ & $74.0 \pm 7.5$ & $70.3 \pm 3.8$ \\
\hline
\end{tabular}

* Mean values \pm SEM; results of experiments shown in Fig. 3 .

\$ Mean values \pm SEM for eight incubations of fed islets and nine incubations of starved islets.

tated by the lesser sensitivity of the protein binding assay) compared to that used (25 islets incubated in $1 \mathrm{ml}$ ) for the radioactive method of measuring cyclic AMP. By contrast, $1.0 \mathrm{mM}$ IBMX (with 3.3 $\mathrm{mM}$ glucose) stimulated similar increases of ${ }^{3} \mathrm{H}$ cyclic AMP (+731\%) and total cyclic AMP (+638\%) in islets of fed rats, and slightly smaller but similar increases of ${ }^{3} \mathrm{H}$ cyclic AMP $(+613 \%)$ and total cyclic AMP $(+571 \%)$ in islets of starved rats.

\section{DISCUSSION}

Contrary to earlier reports $(33,34)$, the ability of glucose to stimulate an increase in the content of cyclic AMP in pancreatic islets has been demonstrated recently by several groups, by using islets isolated with collagenase from adult fed rats (3537 ) or mice (20), as well as islets microdissected from obese (ob/ob) mice (38). The present study also demonstrates that glucose stimulates an increase in the content of cyclic AMP in pancreatic islets of adult fed rats, whether measured as the accumulation of ${ }^{3} \mathrm{H}$ cyclic AMP in islets prelabeled with ${ }^{3} \mathrm{H}$ 2-adenine, or the total amount of the nonradioactive cyclic nucleotide. The glucose-stimulated increase of cyclic AMP in islets of fed rats was rapid, and in static incubations, preceded a significant increase of insulin release (Fig. 2). Also, the insulin and cyclic AMP responses in islets of fed, as well as 48-h starved rats, exhibited parallel glucose dose-dependencies (Fig. 3). This was further emphasized by the strong linear correlations between the insulin and cyclic AMP responses to glucose (Fig. 4).

However, it is also apparent in Fig. 4 that the ratio of insulin release to islet cyclic AMP accumulation was lower in incubations with glucose plus the phosphodiesterase inhibitor, IBMX than with glucose alone. Similarly, Charles et al. (35), and Hellman et al. (38), by employing high concentrations of xanthine derivatives, or the adenylate cyclase stimulator, cholera toxin, have shown that islet concentrations of cyclic AMP even greater than those achieved by high concentrations of glucose are unable to induce major insulin release in the presence of low concentrations of glucose. From these observations it has been concluded that cyclic AMP cannot be the mediator of glucose-induced insulin release. Although cyclic AMP may not be the exclusive mediator of insulin release, nevertheless, the present study suggests that the differences between insulin release in islets of fed and starved rats may be due to differences in activity of the adenylate cyclase-cyclic AMP system in these islets.

The mechanism(s) by which starvation results in impairment of beta cell function are not clear. A role for islet cyclic AMP has been implied by recent studies (18-20). Contrary to the findings of Selawry et al. (19) and in agreement with Capito and Hedeskov (20), the basal content of cyclic AMP was not significantly reduced in islets of starved animals (Table III). However, in agreement with the latter authors (20), glucose stimulated a lesser increase of cyclic AMP in islets of $48 \mathrm{~h}$ starved than fed animals. Since starvation reduced mainly the early phase of glucoseinduced insulin release (Fig. 1 and Table II), it is of particular interest that increases of cyclic AMP in islets of starved rats were less than in islets of fed rats only during the first 10-min of stimulation with glucose. Also, cyclic AMP responses were similar in fed and starved islets at $30 \mathrm{~min}$, and insulin responses were similar at $60 \mathrm{~min}$ (Fig. 2). Thus, there was a parallel impairment in the early insulin and cyclic AMP responses to glucose in islets of 48-h starved rats. In addition, the dose kinetics of the insulin and cyclic AMP responses to glucose were similarly impaired in islets of $48 \mathrm{~h}$ starved rats. Starvation raised the threshold and decreased the capacity of the insulin as well as the cyclic AMP responses to glucose in 10-min incubations (Fig. 3). The similarity in the impairment of both time- and dose-kinetics of glucose-induced insulin and cyclic AMP responses in islets of 48-hr starved rats suggests that a major factor in the modification of glucoseinduced insulin release in starvation may be a reduced responsiveness of the islet cyclic AMP system to glucose.

Inhibition of the phosphodiesterases with IBMX did not fully restore the impaired glucose-stimulated insulin response in starved islets, as reported by others $(11,39)$. However, IBMX amplified the dose-dependent effects of glucose similarly in fed and starved islets, and the sensitivity of insulin re- 
lease to cyclic AMP was similar in fed and starved islets (Fig. 4). This finding suggests that the response of the effector secretory system to the postulated signal derived from cyclic AMP is unaltered by starvation.

Several authors $(2,4,7,16)$ have demonstrated that glucose refeeding in vivo can correct the impaired insulin release associated with starvation, and Hahn and Fiedler (15) recently reported that glucose priming in vitro was also effective. In the present study, a 60 -min preincubation of islets of $48 \mathrm{~h}$ starved rats with $16.7 \mathrm{mM}$ glucose resulted in the restoration of normal (fed) glucose dose-response relationships both for insulin release and cyclic AMP accumulation (Fig. 5). It is quite possible that the time kinetic characteristics of the cyclic AMP and insulin responses in starvation, i.e. their "normalization" at 30 and $60 \mathrm{~min}$, respectively, (Fig. 2), reflect a similar restoring effect of high glucose during prolonged incubations. These findings are of considerable interest since they suggest that starvation (or glucose withdrawal) affects a glucose-sensitive beta cell mechanism which displays a high turnover rate. Having observed that the normalizing effect of glucose "priming" is blocked by actinomycin D, Grey et al. (7) concluded that the impairment of glucosestimulated insulin secretion in starvation is associated with changes in a glucose-inducible enzyme system in the pancreatic beta cell. However, Howell et al. (18) reported that the increase in adenylate cyclase activity in rat islets incubated for $4 \mathrm{~h}$ with $17 \mathrm{mM}$ glucose was not prevented by cycloheximide or actinomycin $\mathrm{D}$. These observations, together with the short-term $(1 \mathrm{~h})$ action of glucose in correcting the impaired insulin and cyclic AMP responses in starvation in the present study, suggest activation of an existing enzyme(s) or "glucoreceptor" rather than their induction by the hexose.

Starvation has been reported to cause a marked reduction of glucose metabolism $(14,39)$ as well as a reduced activity of glucokinase and phosphofructokinase in islets (40). On the basis of these findings, the above authors have proposed that the major starvation-induced defect in the process of glucose recognition in the beta cell is located in the early steps of glucose metabolism through the glycolytic pathway. Our data do not exclude a role for altered glucose metabolism in the anomaly of islet function induced by starvation. The effect of glucose on cyclic AMP may even be linked with its metabolism (37, 38). However, other reports suggest that a defect in cyclic AMP generation, rather than in carbohydrate metabolism, might be responsible for the decreased insulin release observed in starvation. Thus, fasting $\mathrm{ob} / \mathrm{ob}$ mice for $18 \mathrm{~h}$ reduced the initial phase of glucose-induced insulin release, but left the rise of glucose-6-phosphate unaffected (11); and the glucoseinduced increase of cyclic AMP was reduced by $50 \%$ in islets of rats starved for $24 \mathrm{~h}$, whereas glucose oxidation was not affected (41).

In summary, the data presented here suggest that the glucose-stimulated increase of cyclic AMP in islets may be one of the factors that control insulin release; and that the modifications induced by starvation on the metabolism of this nucleotide may be, at least in part, responsible for the impairment of insulin secretion observed in starvation.

\section{ACKNOWLEDGMENTS}

We are grateful to Mrs. Liza Cavillier for her expert and devoted technical help. This work was supported by the Fonds National Suisse de la Recherche Scientifique (grants 3.384.70 and 3.1060.73).

\section{REFERENCES}

1. Cahill, G. F. Jr., M. G. Herrera, A. P. Morgan, J. S. Soeldner, J. Steinke, P. L. Levy, G. H. Reichard, Jr., and D. M. Kipnis. 1966. Hormone-fuel interrelationships during fasting. J. Clin. Invest. 45: 1751-1769.

2. Solomon, S. S., J. W. Ensinck, and R. H. Williams. 1968. Effect of starvation on plasma immunoreactive insulin and non-suppressible insulin-like acitivity in normal and obese humans. Metab. Clin. Exp. 17: 528534.

3. Malaisse, W. J., F. Malaisse-Lagae, and P. H. Wright. 1967. Effect of fasting upon insulin secretion in the rat. Am. J. Physiol. 213: 843-848.

4. Vance, J. E., K. D. Buchanan, and R. H. Williams. 1968. Effect of starvation and refeeding on serum immunoreactive glucagon and insulin levels. J. Lab. Clin. Med. 72: 290-297.

5. Unger, R. H., A. M. Eisentraut, and L. L. Madison. 1963. The effect of total starvation upon the levels of circulating glucagon and insulin in man. J. Clin. Invest. 42: 1031-1039.

6. Lopez-Quijada, C., J. Gomez-Acebo, and E. Blazquez. 1969. Effect of starvation upon insulin secretion in the rabbit. Acta Diabetol. Lat. 6: 820-835.

7. Grey, N. J., S. Goldring, and D. M. Kipnis. 1970. The effect of fasting, diet and Actinomycin $\mathrm{D}$ on insulin secretion in the rat. J. Clin. Invest. 49: 881889.

8. Buchanan, K. D., J. E. Vance, and R. H. Williams. 1969. Effects of starvation on insulin and glucagon release from isolated islets of Langerhans of the rat. Metab. Clin. Exp. 18: 155-162.

9. Matschinsky, F. M., J. E. Ellerman, J. Krzanowski, J. Kotler-Brajtburg, R. Landgraf, and R. Fertel. 1971. The dual function of glucose in islets of Langerhans. J. Biol. Chem. 246: 1007-1011.

10. Bosboom, R. S., J. Zweens, and P. R. Bouman. 1973 Effects of feeding and fasting on the insulin secretory response to glucose and sulfonylureas in intact rats and isolated perfused rat pancreas. Diabetologia. 9: $243-250$

11. Idahl, L. $\AA$. 1973. Dynamics of pancreatic B-cell responses to glucose. Diabetologia. 9: 403-412. 
12. Voyles, N., R. A. Gutman, H. Selawry, G. Fink, J. C. Penhos, and L. Recant. 1973. Interaction of various stimulators and inhibitors on insulin secretion in vitro. Horm. Metab. Res. 4: 65-73.

13. Fink, G., R. A. Gutman, J. C. Cresto, H. Selawry, R. Lavine, and L. Recant. 1974. Glucose-induced insulin release patterns: effect of starvation. Diabetologia. 10: 421-425.

14. Hedeskov, C. J., and K. Capito. 1974. Effect of starvation on insulin secretion and glucose metabolism in mouse pancreatic islets. Biochem. J. 140: 423-433.

15. Hahn, H. J., and H. Fiedler. 1974. Investigations on isolated islets in vitro. IX. Influence of food deprivation and glucose refeeding in vitro on insulin secretion. Acta Diabetol. Lat. 11: 457-467.

16. Turner, D. S., and D. A. B. Young. 1973. The effect of fasting and selective refeeding on insulin release in the rat. Acta Endocrinol. (Kbh.) 72: 46-52.

17. Renold, A. E. 1970. Insulin biosynthesis and secretiona still unsettled topic. N. Engl. J. Med. 282: 173182.

18. Howell, S. L., I. C. Green, and W. Montague. 1973. A possible role of adenylate cyclase in the long-term dietary regulation of insulin secretion from rat islets of Langerhans. Biochem. J. 136: 343-349.

19. Selawry, H., R. Gutman, G. Fink, and L. Recant. 1973. The effect of starvation on tissue adenosine 3'-5'-monophosphate levels. Biochem Biophys. Res. Commun. 51: 198-204.

20. Capito, K., and C. J. Hedeskov. 1974. The effect of starvation on phosphodiesterase activity and the content of adenosine $3^{\prime}: 5^{\prime}$-cyclic monophosphate in isolated mouse pancreatic islets. Biochem. J. 142: 653-658.

21. Hedeskov, C. J., and K. Capito. 1975. The restoring effect of caffeine on the decreased sensitivity of the insulin secretory mechanism in mouse pancreatic islets during starvation. Horm. Metab. Res. 7: 1-5.

22. Lacy, P. E., and M. Kostianovsky. 1967. Method for the isolation of intact islets of Langerhans from the rat pancreas. Diabetes. 16: 35-39.

23. Scott, D. A., and A. M. Fisher. 1938. The insulin and zinc content of normal and diabetic pancreas. J. Clin. Invest. 17: 725-728.

24. Kikuchi, M., A. Rabinovitch, W. G. Blackard, and A. E. Renold. 1974. Perifusion of pancreas fragments: a system for the study of dynamic aspects of insulin secretion. Diabetes. 23: 550-559.

25. Kuo, J. F., and E. C. DeRenzo. 1969. A comparison of the effects of lipolytic and antilipolytic agents on adenosine $3^{\prime}, 5^{\prime}$-monophosphate levels in adipose cells as determined by prior labelling with adenine-8- ${ }^{14} \mathrm{C}$. $J$. Biol. Chem. 244: 2252-2260.

26. Humes, J. L., M. Rounbehler, and F. A. Kuehl. 1969. A new assay for measuring adenyl cyclase activity in intact cells. Anal. Biochem. 32: 210-217.

27. Krishna, G., B. Weiss, and B. B. Brodie. 1968. A simple sensitive method for the assay of adenyl cyclase. J. Pharmacol. Exp. Ther. 163: 379-385.

28. Grill, V. 1975. Glucose-induced cyclic AMP accumulation in islets of Langerhans: its relation to insulin release. Thesis, Karolinska Institute, Stockholm.

29. Gilman, A. G. 1970. A protein binding assay for adenosine 3',5'-cyclic monophosphate. Proc. Natl. Acad. Sci. U. S. A. 67: 305-312.

30. Herbert, V., K.-S. Lau, C. W. Gottlieb, and S. J. Bleicher 1965. Coated charcoal immunoassay of insulin. J. Clin. Endocrinol. Metab. 25: 1375-1384.

31. Hunter, W. M., and F. C. Greenwood. 1962. Preparation of iodine-131 labelled human growth hormone of high specific activity. Nature (Lond.) 194: 495-496.

32. Bergmeyer, H. U., and E. Bernt. 1970. D-GlucoseBestimmung mit Glucose-Oxydase and Reoxydase. In Methoden der Enzymatischen Analyse. Bergmeyer, editor. Verlag-Chemie Weinheim. 1172-1179.

33. Montague, W., and J. R. Cook. 1971. The role of adenosine $3^{\prime}, 5^{\prime}$-cyclic monophosphate in the regulation of insulin release by isolated rat islets of Langerhans. Biochem. J. 122: 115-120.

34. Kuo, W. N., D. S. Hodgins, and J. F. Kuo. 1974. Regulation by various hormones and agents of adenosine 3',5'-monophosphate levels in islets of Langerhans of rats. Biochem. Pharmacol. 33: 1387-1391.

35. Charles, M. A., R. Fanska, F. G. Schmid, P. A. Forsham, and G. M. Grodsky. 1973. Adenosine 3',5'-monophosphate in pancreatic islets: glucose-induced insulin release. Science. (Wash. D. C.) 179: 569-571.

36. Grill, V., and E. Cerasi. 1974. Stimulation by D-glucose of cyclic adenosine $3^{\prime}: 5^{\prime}$-monophosphate accumulation and insulin release in isolated pancreatic islets of the rat. J. Biol. Chem. 249: 4196-4201.

37. Zawalich, W. S., R. C. Karl, J. A. Ferrendelli, and F. M. Matschinsky. 1975. Factors governing glucoseinduced elevation of cyclic $3^{\prime}: 5^{\prime}$ AMP levels in pancreatic islets. Diabetologia. 11: 231-235.

38. Hellman, B., L.-A. Idahl, A. Lernmark, and I.-B. Täljedal. 1974. The pancreatic beta-cell recognition of insulin secretagogues: does cyclic AMP mediate the effects of glucose? Proc. Natl. Acad. Sci. U. S. A 71: 3405-3409.

39. Levy, J., Herchuelz, A., Sener, A., and W. J. Malaisse. 1976. The stimulus-secretion coupling of glucoseinduced insulin release. XX. Fasting: a model for altered glucose recognition by the B-cell. Metab. Clin. Exp. 25: 583-591.

40. Malaisse, W. J., Sener, A., and J. Levy. 1976. The stimulus-secretion coupling of glucose-induced insulin release. Fasting-induced adaptation of key glycolytic enzymes in isolated islets. J. Biol. Chem. 251: 1731-1737.

41. Bouman, P. R., Konijnendijk, W., and G. H. J. Wolters 1975. Effects of fasting on insulin release, cyclic AMP and glucose oxidation in isolated islets of Langerhans (Abstr.). Diabetologia. 11: 334. 